\title{
Does the month of birth influence the prevalence of refractive errors?
}

\section{Czy miesiąc urodzenia wpływa na częstość występowania wad refrakcji?}

\author{
Maciej Czepita1', Leszek Kuprjanowicz', Krzysztof Safranow², Artur Mojsa1, Ewa Majdanik', \\ Maria Ustianowska', Damian Czepita' \\ ${ }^{1}$ Katedra i Klinika Okulistyki Pomorskiego Uniwersytetu Medycznego w Szczecinie \\ al. Powstańców Wlkp. 72, 70-111 Szczecin \\ Kierownik: prof. dr hab. n. med. Wojciech Lubiński \\ ${ }^{2}$ Zakład Biochemii Katedry Biochemii i Chemii Medycznej Pomorskiego Uniwersytetu Medycznego w Szczecinie \\ al. Powstańców Wlkp. 72, 70-111 Szczecin \\ Kierownik: prof. dr hab. n. med. Dariusz Chlubek
}

\section{SUMMARY}

Purpose: The aim of our study was to examine whether the month of birth influences the prevalence of refractive errors. Material and methods: A total of 5,601 schoolchildren were examined $(2,688$ boys and 2,913 girls, aged $6-18$ years, mean age 11.9, SD 3.2 years). The children examined, students of elementary and secondary schools, were Polish and resided in and around Szczecin, Poland. Every examined subject underwent retinoscopy under cycloplegia using 1\% tropicamide. Data analysis was performed using the Kruskal-Wallis test followed by the Siegel and Castellan post-hoc test or the Mann-Whitney U-test. P values of $<0.05$ were considered statistically significant.
Results: Students born in June had significantly higher spherical equivalents than schoolchildren born in May $0.66 \pm 1.17$ and $0.39 \pm 1.17$ respectively, $p=0.0058$ ). The Mann-Whitney U-test showed that students born in June had significantly higher spherical equivalents than schoolchildren born in any other month $(0.66 \pm 1.17$ and $0.50 \pm 1.17$ respectively, $p=0.0033$ ). Besides that, we did not observe any other association between refractive errors and the month of birth.

Conclusion: Children born in Poland in June may have a higher spherical equivalent.

Key words: month of birth, refractive errors, children, Poland.

\section{STRESZCZENIE}

Wstęp: Celem pracy jest sprawdzenie, czy urodzenie się w danym miesiącu wpływa na częstość występowania wad refrakcji. Materiał i metody: Przebadano 5601 uczniów - 2688 chłopców i 2913 dziewczynek w wieku 6-18 lat (średnia 11,9 \$3,2). Badane dzieci uczęszczały do szkół podstawowych i średnich, były narodowości polskiej, mieszkały w Szczecinie i jego okolicach. U wszystkich badanych osób wykonano skiaskopię po cykloplegii 1-procentowym tropikamidem. Analizę danych przeprowadzono testem Kruskala-Wallisa, a następnie testem post-hoc Siegela i Castelaniego lub testem U Manna-Whitneya. Przyjęto poziom istotności $\mathrm{p}<0,05$.
Wyniki: Uczniowie urodzeni w czerwcu mają wyższy ekwiwalent sferyczny niż uczniowie urodzeni w maju (odpowiednio $0,66 \pm 1,17$ i $0,39 \pm 1,17, p=0,0058$ ). W teście U Manna-Whitneya wykazano, że uczniowie urodzeni w czerwcu mają wyższy ekwiwalent sferyczny niż uczniowie urodzeni w jakimkolwiek innym miesiącu (odpowiednio 0,66 $\pm 1,17$ i $0,50 \pm 1,17, p=0,0033$ ). Poza tym nie zaobserwowano żadnej innej asocjacji pomiędzy wadami refrakcji a miesiącem urodzenia.

Wniosek: Dzieci urodzone w Polsce w czerwcu mogą mieć wyższy ekwiwalent sferyczny.

Słowa kluczowe: miesiąc urodzenia, wady refrakcji, dzieci, Polska.

\section{INTRODUCTION}

Investigations into the influence of ambient lighting at night and the incidence of refractive errors were begun in 1999 by Quinn et al. [1]. Research done by this group indicated that the prevalence of myopia during childhood was associated with ambient exposure during sleep at night in the first two years after birth.

These results were confirmed by Chapell et al. [2], after examining children and adults in the USA, and by Czepita et al. $[3,4]$ reporting on Polish students.

However, an association between the incidence of myopia and sleeping in a light room until the second year of age was not determined by Gwiazda et al. [5], Mutti et al. [6] or Stone et al. [7] on a population of American children, Guggenheim et al. [8] on a population of UK students, Saw et al. $[9,10]$ on a population of Singaporean children, Sugimoto et al. [11] on a population of Japanese children or Czepita et al. [12] on a population of Polish students.

So far research into the association of myopia and the month of birth has been conducted in China [13], Finland [14], Israel [15], United Kingdom [16, 17] and United States of America [18]. The obtained results are varied.

Therefore, the aim of our study was to examine whether the month of birth influences the prevalence of refractive errors. 


\section{MATERIAL AND METHODS}

A total of 5,601 schoolchildren - 2,688 boys and 2,913 girls aged 6-18 years (mean $11.9 \pm 3.2$ ) were examined. The children examined, students of elementary and secondary schools, were Polish and resided in and around Szczecin, Poland. The students examined were Caucasian, and there were no children of mixed ethnicity.

Participation in the study was voluntary. Before beginning the examinations the doctors met with the children, their parents or legal guardians and teachers. It was explained what the examinations were about. The children, parents or legal guardians and teachers had an opportunity to discuss the study with the investigators prior to giving consent. Informed consent as well as date of birth was obtained in each case from children, parents or legal guardians and school principals. The studies were approved by the Bioethics Committee of the Pomeranian Medical University in Szczecin. The research protocol complied with the provisions of the Declaration of Helsinki for research involving human subjects.

In each month $417 \pm 33$ subjects were examined. According to the Federal Ministry of Transport and Digital Infrastructure (www.dwd.de/mittelwerte. 2014) the sun's exposition in the course of the conducted study was $143.8 \pm 79.5$ hours a month [19] - Table 1.

Every examined subject underwent retinoscopy under cycloplegia. Cycloplegia was induced with two drops of $1 \%$ tropicamide administered 5 min apart. Thirty minutes after the last drop, pupil dilation and the presence of light reflex was evaluated as later retinoscopy was performed. Retinoscopy was performed in the schools' darkened consulting rooms.

The refractive error readings were reported as a spherical equivalent (SE; sphere power plus half negative cylinder power). Hyperopia was defined to be spherical equivalent higher than +0.5 D and emmetropia to be higher than -0.5 and lower than +0.5 D. Myopia was defined to be with an SE lower than -0.5 D. The mean SE was calculated after the examination of both eyes.

According to Zadnik et al. [20] 95\% limits of agreement for cycloplegic retinoscopy are $\pm 0.95 \mathrm{D}$.

The obtained results were entered into an Excel spreadsheet and processed using Statistica 10 software. Data analysis was performed using the Kruskal-Wallis test followed by the Siegel and Castellan post-hoc test or the Mann-Whitney U-test. P values of $<0.05$ were considered statistically significant.

\section{RESULTS}

The obtained results are presented in Figure 1. There were significant differences between months ( $p=0.0050$, KruskalWallis test). Siegel and Castellan post-hoc analysis of differences for each pair of months showed that students born in June had significantly higher spherical equivalents than schoolchildren born in May ( $0.66 \pm 1.17$ and $0.39 \pm 1.17$ respectively, $p=0.0058)$. The Mann-Whitney U-test showed that students born in June had significantly higher spherical equivalents than schoolchildren born in any other month $(0.66 \pm 1.17$ and $0.50 \pm 1.17$ respectively, $\mathrm{p}=0.0033$ ). Besides that, we did not observe any other association between refractive errors and the month of birth.

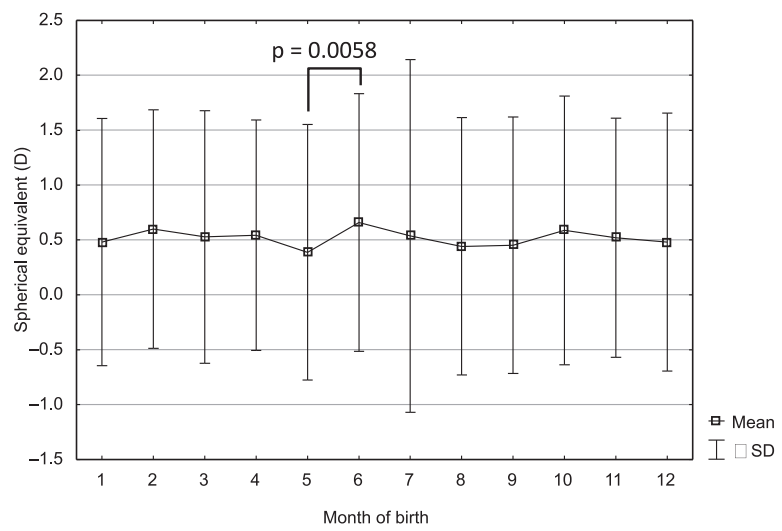

FIGURE 1. Mean spherical equivalent in relation to the month of birth

\section{DISCUSSION}

A few papers concerning the association between the incidence of refractive errors and the month of birth have so far been published [13, 14, 15, 16, 17, 18].

In 2003 Vannas et al. [14] examined 3,524 Finish army conscripts aged 17-30 years old, and observed that the prevalence of myopia was higher among those people living above the Arctic Circle. The authors did not find an association between the incidence of myopia and the month of birth.

However, Mandel et al. [15] after examining 276,911 Israeli army conscripts aged 16-22 years, determined that myopia occurs more often in those people born during the summer months.

A similar association was observed in the UK by McMahon et al. [16], who examined 74,459 people aged 18-100 years.

Deng and Gwiazda [18] from the US observed that infants born in the photoperiod group with the most daylight hours

TABLE 1. Number of schoolchildren and the sun's exposition in examined months

\begin{tabular}{|c|c|c|c|c|c|c|c|c|c|c|c|c|}
\hline & \multicolumn{12}{|c|}{ Month of birth } \\
\hline & Jan & Feb & Mar & Apr & May & Jun & Jul & Aug & Sep & Oct & Nov & Dec \\
\hline $\mathrm{n}$ & 491 & 483 & 479 & 466 & 513 & 480 & 503 & 483 & 431 & 429 & 417 & 426 \\
\hline $\begin{array}{l}\text { Sun's exposition } \\
\text { (h/month) }\end{array}$ & 50 & 70 & 122 & 192 & 243 & 224 & 244 & 217 & 158 & 117 & 51 & 38 \\
\hline
\end{tabular}


had slightly lower refractions than those in the shortest photoperiod group.

Pearce and Dunbar [17] found that a significant positive relationship between absolute latitude and the human orbital volume exists based on research conducted on 73 adult crania obtained from the Oxford Museum of Natural History, and the Duckworth Collection of University of Cambridge in the UK. The authors also concluded that visual acuity measured under full-daylight conditions is constant across latitudes.

Recently, Ma et al. [13], after examining 1,219 children aged 0-3 years residing in eastern China, determined that children born in winter had a more myopic refraction compared with those born in other seasons.

Our research is the first to be conducted in Poland. We found a higher refraction of $0.16 \mathrm{D}$ in students born in June than in any other month. Besides that, we did not observe any other association between the incidence of refractive errors and the month of birth.

The results obtained by us are in agreement with those of Vannas et al. [14], who did not find an association between the incidence of myopia and the month of birth. Our results differ from those of Mandel et al. [15], McMahon et al. [16], Deng and Gwiazda [18], Ma et al. [13], who did find an association between the incidence of myopia and the month of birth. These authors did not examine the patients after cycloplegia, and therefore the results are probably not credible.

The underlying biological mechanism for this association has so far not been explained. This might be due to changes in the function of muscarinic, nicotinic and dopaminergic receptors. In the latest papers, a possible role of ambient lighting at night, diurnal rhythms as well as intrinsic retinal circadian rhythms have been proposed in the development of the eye $[21,22]$. Therefore, further studies dealing with this topic are needed.

\section{CONCLUSION}

Children born in Poland in June may have a higher spherical equivalent.

\section{REFERENCES}

1. Quinn G.E., Shin C.H., Maguire M.G., Stone R.A.: Myopia and ambient lighting at night. Nature. 1999, 399 (6732), 113-114.
2. Chapell M., Sullivan B., Saridakis S., Costello L., Mazgajewski N., McGinley J. et al: Myopia and night-time lighting during sleep in children and adults. Percept Mot Skills. 2001, 92, 640-642.

3. Czepita D., Gosławski W., Mojsa A.: Occurrence of refractive errors among students who before the age of two grew up under the influence of light emitted by incandescent or fluorescent lamps. Ann Acad Med Stetin. 2005, 51 (1), 33-36.

4. Czepita D., Gosławski W., Mojsa A., Muszyńska-Lachota I.: Role of light emitted by incandescent or fluorescent lamps in the development of myopia and astigmatism. Med Sci Monit. 2004, 10 (4), CR168-171.

5. Gwiazda J., Ong E., Held R., Thorn F.: Myopia in children is not associated with night-time lighting in infancy. In: Proceedings of the VIII International Conference on Myopia. Eds: F. Thorn, D. Troilo, J. Gwiazda. Conference on myopia 2000, Boston 2000, 308-312.

6. Mutti D.O., Jones L.A., Irvin B.C., Kleinstein R.N., Manny R.E., Shinny J.A. et al.: Nursery lighting is not associated with myopia. In: Proceedings of the VIII International Conference on Myopia. Eds: F. Thorn, D. Troilo, J. Gwiazda. Conference on myopia 2000, Boston 2000, 313-316.

7. Stone R.A., Wilson L.B., Ying G.S., Liu G.S., Criss J.S., Orlow J. et al.: Association between childhood refraction and parental smoking. Invest Ophthalmol Vis Sci. 2006, 47 (10), 4277-4287.

8. Guggenheim J.A., Hill C., Yam T.F.: Myopia, genetics, and ambient lighting at night in a UK sample. Br J Ophthalmol. 2003, 87 (5), 580-582.

9. Saw S.M., Wu H.M., Hong C.Y., Chua W.H., Chia K.S., Tan D.: Myopia and night lighting in children in Singapore. Br J Ophthalmol. 2001, 85 (5), 527-528.

10. Saw S.M., Zhang M.Z., Hong R.Z., Fu Z.F., Pang M.H., Tan D.T.: Near-work activity, night-lights, and myopia in the Singapore-China study. Arch Ophthalmol. 2002, 120 (5), 620-627.

11. Sugimoto R., Kuwayama Y., Stone R.A.: Myopia and night-time light exposure in Japanese schoolchildren. Invest Ophthalmol Vis Sci. 2001, Suppl., 42, S392.

12. Czepita D., Mojsa A., Czepita M., Lachowicz E.: Myopia and night lighting. Investigations on children with negative family history. Klin Oczna. 2012, 114 (1), 22-25.

13. Ma Q., Xu W., Zhou X., Cui C., Pan C.W.: The relationship of season of birth with refractive error in very young children in eastern China. PLOS ONE 2014, 9 (6), e100472, doi: 10.1371/journal.pone.0100472.

14. Vannas A.E., Ying G.S., Stone R.A., Maguire M.G., Jormanainen V., Tervo T. et al:: Myopia and natural lighting extremes: risk factors in Finnish army conscripts. Acta Ophthalmol Scand. 2003, 81 (6), 588-595.

15. Mandel Y., Grotto I., El-Yaniv R., Belkin M., Israeli E., Polat U. et al.: Season oh birth, natural light, and myopia. Ophthalmology. 2008, 115, 686-692.

16. McMahon G., Zayats T., Chen Y.P., Prashar A., Williams C., Guggenheim J.A.: Season of birth, daylight hours at birth, and high myopia. Ophthalmology. 2009, 116 (3), 468-473.

17. Pearce E., Dunbar R.: Latitudinal variation in light levels drives human visual system size. Biol Lett. 2012, 8 (1), 90-93.

18. Deng L., Gwiazda J.: Birth season, photoperiod, and infancy refraction. Optom Vis Sci. 2011, 88 (3), 383-387.

19. Federal Ministry of Transport and Digital Infrastructure. 2015; www. dwd.de/mittelwerte (2.04.2015)

20. Zadnik K., Mutti D.O., Adams A.J.: The repeatability of measurement of the ocular components. Invest Ophthalmol Vis Sci. 1992, 33 (7), 2325-2333.

21. Czepita D.: Myopia - incidence, pathogenesis, management and new possibilities of treatment. Russ Ophthalmol J. 2014, 7, 96-101.

22. Stone R.A., Pardue M.T., Iuvone P.M., Khurana T.S.: Pharmacology of myopia and potential role for intrinsic retinal circadian rhythms. Exp Eye Res. $2013,114,35-47$ 